\title{
Utilization of Rice Straw Waste in The Production of Crude Cellulase by Aspergillus Niger for Biodeingking Processes
}

\author{
Yanty Maryanty ${ }^{1}$, Kristina Widjayanti ${ }^{1}$, Sri Rulianah ${ }^{1}$, Meiliefiana ${ }^{1}$, and Windra Putri Juwita ${ }^{1}$
}

\begin{abstract}
Rice straw is agricultural waste that contains cellulose and has not been used optimally. The agricultural wastes contain cellulose which can be utilized for the production of cellulase enzymes. Cellulase produced from cellulose hydrolysis process in such materials through enzymatic hydrolysis. This study aimed to determine the effect of substrate type and temperature delignification on cellulase enzyme production and determine the effect of the number of additional enzymes of each substrate at biodeinking process. Variable used is the temperature used in the delignification process $(100 \mathrm{oC}$ and $1200 \mathrm{o})$, the addition of substrate (2,3,4,5,6\%), additional doses of the application biodeinking (1,2,3,4,5\%). Research conducted by softening rice straw to 30 mesh size media then delignification using $100{ }^{\circ} \mathrm{C}$ and $120^{\circ} \mathrm{C}$ for 150 minutes, and fermented with Aspergillus niger in liquid inoculum, growth curves, and the crude cellulase production. The resulting crude cellulase was applied to the process biodeinking. Fieldwork results showed that at a temperature of $120 \mathrm{oC}$ delignification can reduce lignin content in straw was $48.7 \%$. Highest crude cellulase activity of delignification results $1200 \mathrm{C} 4 \%$ resulting from the addition of media on the production of the enzyme activity of crude enzyme with 118.055 units / ml. Biodeinking application results showed that the addition of $3 \%$ crude cellulase with medium straw delignification results of $1200 \mathrm{C}$ can raise the value of paper brightness of $35.39 \%$ to $42.86 \%$ or $17: 42 \%$.
\end{abstract}

Keywords_- straw, delignification, $\mathrm{NaOH}$.

\section{INTRODUCTION}

$\mathrm{I}_{\mathrm{n}}^{\mathrm{n}}$ $\mathrm{n}$ this era, the reduced availability of raw materials from the original pulp paper industry (virgin pulp) and paper from natural fibers, paper encourages the industry to seek alternative raw materials, namely the re-use of waste paper. (Rismijana et al, 2002). One of the difficulties in the processing of waste paper as a source of secondary fiber is the process of removing contaminants ink. Contaminant removal technology ink (deinking) seems more likely towards khlordioksida and oxygen consumption for prebleaching. (Rismijana et al, 2008).

Biodeinking is the process of deinking waste paper with the help of biological compounds such as enzymes. Enzymes which can be used eg cellulase enzyme (Anonymous, 2009). Cellulase can be produced by fungi, bacteria, and ruminants. Commercial production of enzymes typically using fungi or bacteria. Types of fungi commonly used in the production of cellulase is Aspergillus niger (Usama et al, 2008: Immanuel et al, 2006: Ikram et al, 2005: Omojasola et al, 2008: Narasimha G et al, 2006). Aspergillus niger is a fungus that can degrade cellulose lignoselulotik (Soetopo et al, 2008). The medium used to produce the enzyme cellulase is cellulose-containing media such as timber (Afandi, 2007). Wood is divided into 2 kinds of hardwood and softwood. The types of softwood trees are pine, spruce, cedar, fir fir, larch, douglas fir, rice straw, etc., while Example hardwood species: mahogany, teak, walnut, oak, ash, elm, aspen, birch , maple (Anonymous, 2013).

In this research is to produce cellulase enzyme with substrate hardwood (mahogany) and softwood (rice

${ }^{1}$ Yanty Maryanty, Kristina Widjayanti, Sri Rulianah, Meiliefiana, and Windra Putri Juwita are with Departement of Chemica Engineering, Politeknik Negeri Malang, Malang, Indonesia. E-mail: yantyerik.maryanty@gmail.com. straw) which is the furniture industry waste and agricultural waste are abundant in number in the district of Malang. Material - the material is subjected to delignification through the addition of chemical methods, namely by penmabahan alkali $(\mathrm{NaOH})$. Caustic soda or lye $\mathrm{NaOH}$ is the most potent in degrading the cell wall structure (Marjuki, 2013).

\section{MATERIALS AND METHODS}

\section{A. Microorganisms}

Aspergillus niger was purchased from Brawijaya University Malang-Indonesia. The strains were grown on potato dextrose agar medium.

\section{B. Chemical delignification of rice straw using $\mathrm{NaOH}$}

Rice straw cleaned and cut into pieces in a small size. taken a little rice straw and lignin content analysis before delignification process. A total of 20 grams of powdered rice straw soaked with $8 \% \mathrm{NaOH}$ at a temperature of $120 \mathrm{oC}$ and $100 \mathrm{oC}$ for 150 menit.Hasil delignification washed and filtered and dikerongkan in the oven until the weight of the dry weight konstan.Hasil analyzed lignin content after delignification process.

\section{Analysis Of Lignin}

Rice straw powder weighed 1 gram in $100 \mathrm{ml}$ glass beaker. $72 \% \mathrm{H} 2 \mathrm{SO} 4$ solution was added as much as 15 $\mathrm{ml}$. The mixture was stirred gently until evenly distributed. Then allowed to stand for 2 hours while stirring occasionally and transferred into a $500 \mathrm{ml}$ Erlenmeyer flask. Mixture was added $500 \mathrm{ml}$ of distilled water to the limit. And boiled in water bath for 4 hours. The precipitate is filtered with a filter paper and washed with distilled water until neutral $\mathrm{pH}$. The result weighed until a constant dry weight. And calculated the results.

Calculation of lignin content $(\%)=($ sediment weight $) /$ (initial weight of the sample) x 100. 


\section{Culture and fermentation medium}

Rice straw weighed as much as 2.5 grams. Then added $250 \mathrm{ml}$ nutrient $(0.025 \mathrm{~g}$ yeast extract, $0.125 \mathrm{~g}$ polypeptone, 0.025 K2HPO4, 0:05 MgSO4.7H2O gr 3\% sucrose and dissolved in $500 \mathrm{ml}$.) And sterilized in the autoclave for 30 minutes at a temperature of niger 121oC.Aspergillus added as 1 loop into the liquid medium. 5x24 then incubated for 25 hours at a temperature of-30oC and with a speed of $150 \mathrm{rpm}$.

\section{E. Production of crude cellulase enzyme}

Rice straw weighed 2.5 grams which is milled according to size. Then added $50 \mathrm{ml}$ nutrient $(0.025 \mathrm{~g}$ yeast extract, $0.125 \mathrm{~g}$ polypeptone, 0.025 K2HPO4, 0:05 MgSO4.7H2O gr 3\% sucrose and dissolved in $500 \mathrm{ml}$ ). And sterilized in an autoclave at a temperature of $1210 \mathrm{C}$ for 30 minutes. The result is cooled to lukewarm. Aspergillus niger inoculum was added as much as $10 \%$ of the media volume cair.Dan incubated with rotary speed of $150 \mathrm{rpm}$ at a temperature of $25-30 \mathrm{oC}$ for 84 hours. The results are filtered using Whatman filter paper no. 41 (filtrate analyzed). Filtrate centrifuged at $4^{\circ} \mathrm{C}$ with a speed of $2000 \mathrm{rpm}$ for 20 minutes. Results from centrifuge tested cellulase activity.

\section{F. Cellulase Activity USING CMC-ASE}

The substrate is made of $1 \mathrm{ml}$ of $1 \%$ CMC was diluted up to 104 times inserted into a test tube. The samples were made of substrate was added $1 \mathrm{ml}$ of crude enzyme (crude extract). Sample was added $1 \mathrm{ml}$ of free water reducing agent and $1 \mathrm{ml}$ Nelson reagent, tubes covered with aluminum foil and heated in boiling water for 20 menit.Sampel cooled into cold water and add $1 \mathrm{ml}$ arsenomolibdat beat until homogeneous and allowed to stand a few minutes. Each measured absorbance at $\lambda 540$ nm.

\section{G. Biodeingking application}

Biodeingking application done in paper mill PT Ekamas Fortuna Malang, East Java, using the former newspaper paper, the analysis results in the form of a sheet of paper and compared with the usual deingking methods in paper company.

\section{RESULT}

\section{A. Analysis of Lignin Media}

Lignin is an aromatic polymer that is currently associated with secondary cell wall polysaccharides in plants that work to form strong cell structure and protect plants from bacteria (Hendriks, 2008).

A growing number of lignin contained in the media more and more difficult penetration of microorganisms to digest cellulose in the media. Case is due to an increasing number of increasingly close lignin in plant cell or bond that gives resistance to the penetration of microbes to digest the cellulose in the media. In plants, lignin serves as the glue in plant cells and provides rigidity in the cell (Christiani, 2008).

\section{B. Delignification media}

The presence of lignin serves as the glue in the wood cells and provide rigidity in the cell, which reduces the effect dimensional changes with respect to changes in the water timber and minimize the degradation of the cellulose (Haygreen and Bowyer, 1989). For that we need the delignification process that aims to break down or reduce lignin content making it easier for microorganisms to digest cellulose. Delignification is done through two stages, namely the first stage and second stage. The first stage is the drying process and the second stage is the stage of immersion. Aims to simplify the process of drying the rice milling process. Milling aims to cut the length of the polymer chains become shorter and open structure of the cell wall. The second stage is the immersion medium with $\mathrm{NaOH}$. Selection of $\mathrm{NaOH}$ to degrade lignin because $\mathrm{NaOH}$ is a strong oxidant that can easily degrade the hydrolysis lignin molecules (Refi Arioen: 2011)

After delignifikasi process, the lignin content in the hay down from $12,555 \%$ to $9.48 \%$ and $6,435 \%$ or by $25 \%$ and $50 \%$. While the content mahogany ligninnya down from $27.25 \%$ to $20.59 \%$ and $20.3 \%$ or as much as $24 \%$ and $25 \%$. Or reduction of lignin degradation is caused by immersion in alkaline media or $\mathrm{NaOH}$. $\mathrm{NaOH}$ can reduce hydrogen bonds in cellulose crystal molecules so swollen cellulose and cellulose crystals decreases. Cellulose inflate causing discord and lignohemiselulosa lignocellulosic bonds and break up the cell walls become weak.

And the reduction in the cellulose crystals cause the cell wall structure change due to the loss of the acetyl group and phenolic acid groups, as well as the dissolution of silica and hemicellulose hydrolysis of hemicellulose bonds. Due to hydrolysis of hemicellulose and lignin bond, the bond broke and weakened cell walls and lignin soluble in alkaline solution or $\mathrm{NaOH}$ (Marjuki, 2013).

Decrease in lignin content is most prevalent at temperatures of $120 \mathrm{oC}$ delignification, meaning the higher temperatures used for delignification process more and more lignin dissolved or degraded by $\mathrm{NaOH}$ solution. This is because the higher the temperature the more energy is generated in the process of delignification, hydrolysis lignin so that more and more frequently in the media. The dissolution of lignin caused by the transfer of hydrogen ions from the hydroxyl groups of lignin to hydroxyl ions in $\mathrm{NaOH}$ (Gillingan, 1974).

\section{Analysis of Enzyme Activity}

Enzyme activity is known from the amount of glucose produced by the crude enzyme. An extra cellular cellulase enzyme complex consisting of endo-1,4- $\beta$ glukonase, exo- $\beta-1,4$ glukonase, and $\beta$-1,4-glucosidase (Anja Meryandini, 2009). The enzyme complex that plays a role in the formation of glucose into the 
measurement of enzyme activity indicator. Endo-1,4- $\beta$ glukonase cuts the chain amorphous cellulose group, whereas exo- $\beta-1,4$ glukonase cutting force reduction charge between chains of cellulose and cellulose peeling structure forming glucose and cellobiose. Dann selodekstrin cellobiose formed later broken by $\beta-1,4-$ glucosidase to form glucose.

Analysis of glucose produced by enzyme shown in the chart above using Somogyi Nelson method and standard curve of glucose with spectophotometric. Nelson serves as an oxidizing reagent between $\mathrm{Cu} 2 \mathrm{O}$ with reducing sugars to form glucose or brick red precipitate or as a catalyst that reduces $\mathrm{Cu} 2 \mathrm{O}$ into $\mathrm{Cu} 2 \mathrm{O}$ equivalent according to the amount of reducing sugar or glucose that of the crude enzyme (Vogel, 1994). Precipitate formation process is assisted by the heating process to accelerate the reaction by increasing the kinetic energy of molecules that can increase the speed of the reaction. After heating, the sample was cooled and added to dissolve the precipitate reagents arsenomolibdat $\mathrm{Cu} 2 \mathrm{O}$ sample and the color changes to blue.

From the above curve is obtained crude enzyme activity decreased with increasing media used in the production process. It applies to media tersbut delignification results $100 \mathrm{oC}$ and $120 \mathrm{oC}$. Highest enzyme activity of $100 \mathrm{oC}$ delignification proceeds generated from the addition of $3 \%$ in the medium crude enzyme production by enzyme activity 94.44 units / ml of media hay while the addition of $3 \%$ resulting from the production of media in the crude enzyme with enzyme activity 83.68 units / $\mathrm{ml}$.

The results of the activity of crude enzyme delignification hadil $100 \mathrm{oC}$ and $120 \mathrm{oC}$ decreased with increasing media used in the production process due to the addition of more and more media on the production of crude enzyme more residual lignin that inhibit Aspergillus niger to digest cellulose.

\section{Biodeinking Application}

A series of processing stages of deinking waste paper, both conventional and enzymatic (biodeinking) is the same: the decomposition stage, the stage of the release of ink and ink separation stage. The main thing that differentiates between conventional systems and is at the stage of release biodeinking ink. In the conventional deinking, the release of ink done chemically by adding alkaline compounds to give the effect of swelling the fiber (fiber swelling), saponification hydrocarbons (carrier) which is in the process of hydrolysis and ink and ink dispersion. Other chemical compounds were added functions to maintain fiber quality, stability and effectiveness during the release process and the separation of ink. At biodeinking, an enzyme used to partially replace the function of the chemicals used in conventional deinking process (Dina and Elyani: 2009). The addition of crude enzyme in this process can generally increase the value of the paper brightnes 35.89 (blank) a maximum brightness value of 42.03 . From the above graph paper brightnes value of crude enzyme delignification results $100 \mathrm{oC}$ with medium straw highest dose of 42.03 with the addition of the enzyme $3 \%$.

For paper brightnes value of crude enzyme delignification results $1200 \mathrm{C}$ with medium straw highest dose of $42.86 \%$ with the addition of the enzyme $3 \%$. Changes in the value of paper brightness biodeinking seluase caused by the addition of an enzyme that helps break the bond Atar cellulose fibers and effect meningatkan peeling or flaking ink with fiber.

\section{CONCLUSION}

Based on the present study, delignification process with $8 \% \mathrm{NaOH} 120 \mathrm{oC}$ can degradation lignin content of rice straw from $12.55 \%$ to $6.435 \%$ (a decrease of $48.7 \%$ ). Crude cellulase activity on media tallest straw delignification results $120 \mathrm{oC}$ at 118.055 units / $\mathrm{ml}$. for application use traditional biodeinking crude cellulase best results in the addition of crude enzyme with medium straw delignification results $120 \mathrm{oC}$ with the addition of the enzyme dose $3 \%$, and can raise the value of brightness from $35.86 \%$ to $42.86 \%$ (an increase of $17.42 \%)$.

\section{ACKNOWLEDGEMENT}

The authors express their sincere thanks to direktorat jendral pendidikan tinggi (DIKTI) Indonesian Government for the financial support through Competition Grant.

\section{REFERENCES}

[1]. Ikram-ul-haq, Muhammad Mohsin Javed, Saleem Khan and Tehmina Zafar Siddiq. , 2005. Cotton Saccharifying Activity of Cellulases Produced by Co-culture of Aspergillus niger and Trichoderma viride. Res. J. Agric and Biol. Sci. 1 (3) :241-245.

[2]. Marjuki: 2013.Metode waste processing for animal feed. Brawijaya Univ

[3]. Marsden, W.L and P.P. Gray. , 1986. Cellulases in Enzymatic Hydrolysis of lignocellulosic materials. CRC. Critical Rev. in Biotechnol. 3: 235-276

[4]. Narasimha, G, Sridevi A. Buddolia Viswanath, Chandra Subbosh M., B. Rajashekar Reddy 2006. Nutrient Effects on Production of Cellulolytic Enzymes by Aspergillus niger. African Journal of Biotechnology Vol. 5 (5), pp. 472-476.

[5]. Ohara, H., S. Karita, T. Kimura, and K. K.Sakka Ohmiya. 1998. Complex Cellulase from Ruminococcus albus. Annual Report IC Biotech Vol. 21. 358

[6]. Omojasola, P. Folakemi, Priscilla Omowumi Jilani, S. A. Ibiyemi. , 2008. Cellulase Production by some Fungi Cultured on Waste Pineapple. Nature \& Science 6 (2), pp. 64-75

[7]. Rismijana J., Iin Naomi I., and Tutus P: 2002: The use of cellulase-hemicellulase the deinking process of waste newspaper: News Cellulose, Vol 38, No.3-4: 44-50

[8]. Rismijana J., Nina E., and Grandchildren: 2006: Effectiveness biodeinking on the processing of mixed waste paper: Cellulose News Vol.41 \# 1: it 14-20.

[9]. Saha, B.C. , 2003. Bioconversion hemicellulose. J. Ind. Microbiol. Biotechnol. 30: 279-291.

[10]. Saha, B.C. , 2004. Lignocellulose Biodegradation and Applications in Biotechnology. U.S. Government Work. American Chemical Society. 2-14. 


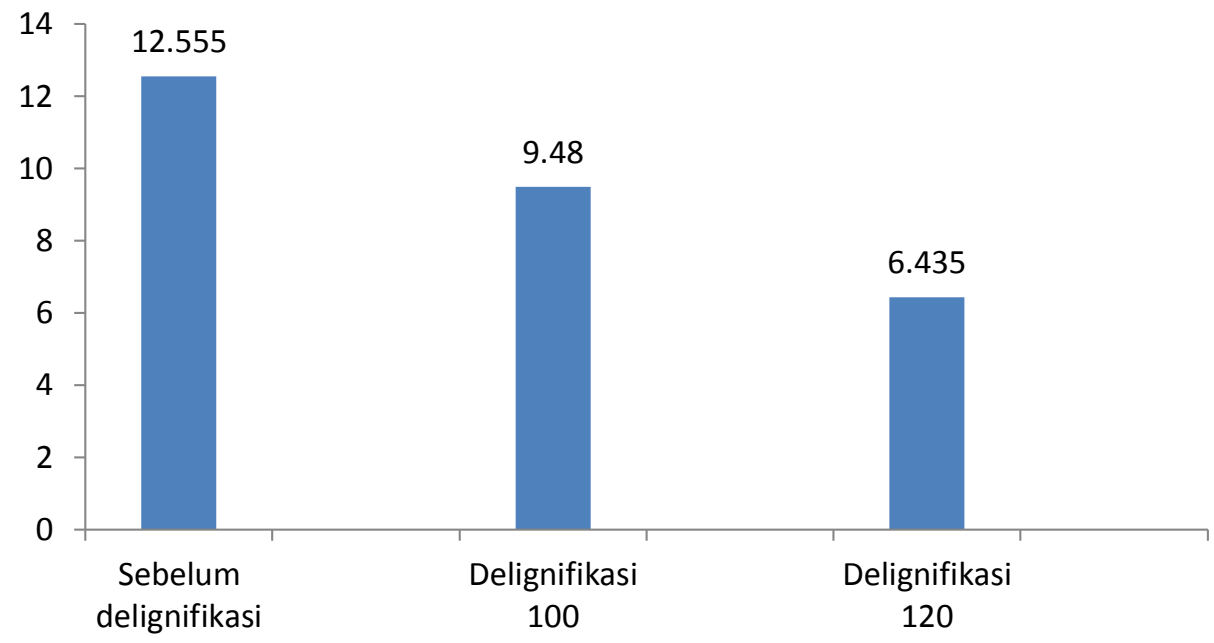

Figure 1. Comparative Analysis of Media Straw Lignin Before and After delignification

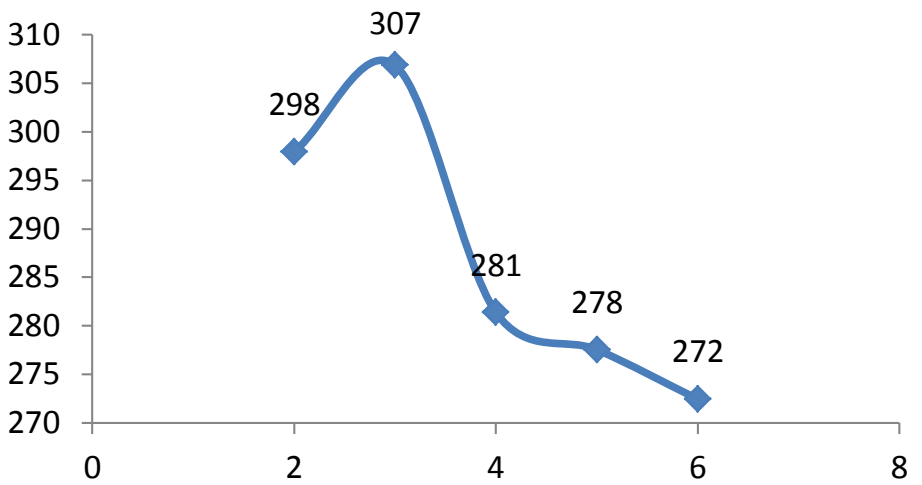

Figure 2. Result Analysis of Enzyme Activity In Media delignification results $100^{\circ} \mathrm{C}$

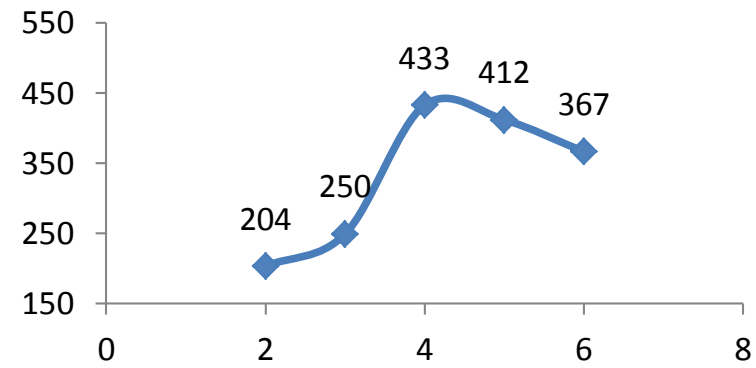

Figure 3. Result Analysis of Enzyme Activity In Media delignification results $120^{\circ} \mathrm{C}$

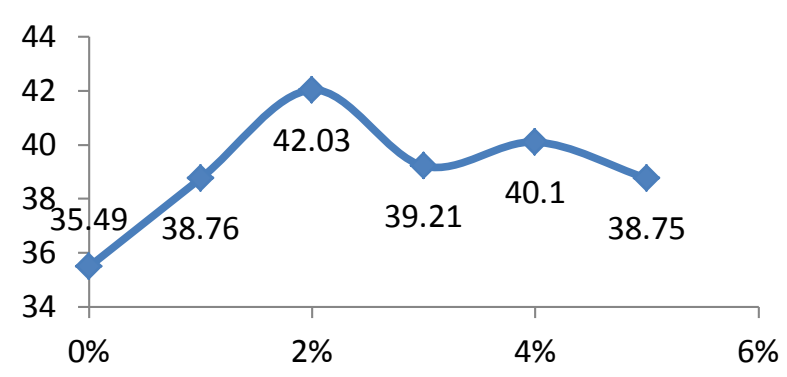

Figure 4. The result of the application Biodeinking Crude Cellulase delignification results $100^{\circ} \mathrm{C}$

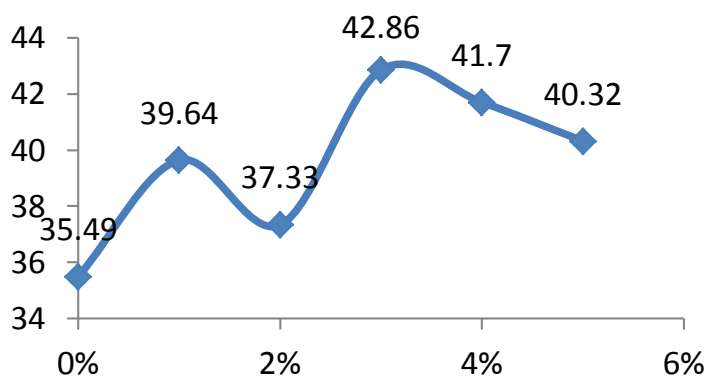

Figure 5. The result of the application Biodeinking Crude Cellulase delignification results at $120^{\circ} \mathrm{C}$

TABLE 1.

ANALYSIS OF STRAW LIGNIN MEDIA

\begin{tabular}{|c|c|c|c|}
\hline \multirow{2}{*}{ Media } & \multicolumn{2}{|c|}{ Lignin Straw (\%) } & \multirow{2}{*}{ On the average } \\
\hline & 1 & 2 & \\
\hline Straw & 12.41 & 12.7 & 12.555 \\
\hline
\end{tabular}

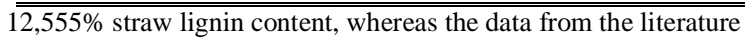
mentions straw lignin content of $12 \%$ (Saffan.wordpress: 2008). 